\title{
NILAI KESEJAHTERAAN PELAKU SENI RONGGENG AMEN SEBAGAI PENDUKUNG PARIWISATA DI KABUPATEN PANGANDARAN
}

\author{
Oleh \\ Rahmat Priyanto' $^{1)}$, Vivih Vira Yuniar ${ }^{2)}$ \& Yuliana Pinaringsih Kristiutami ${ }^{3)}$ \\ 1,2STP ARS Internasional \\ ${ }^{3}$ Akademi Pariwisata BSI Bandung \\ Email: ${ }^{1}$ rahmat.rmp@ bsi.ac.id, ${ }^{2}$ vivihviray@ gmail.com \&

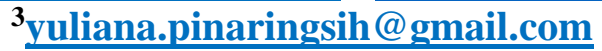

\begin{abstract}
Abstrak
Pantai Pangandaran menjadi salah satu sektor yang paling populer dimana terjadi pengingkatan jumlah wisatawan pada setiap tahunnya. Namun kurangnya pengelolaan secara maksimal terhadap wisata budaya berdampak terhadap kondisi kesejahteraan pelaku seni Ronggeng Amen. Penelitian ini bertujuan untuk mengetahui tingkat kesejahteraan pelaku seni Ronggeng Amen di Kabupaten Pangandaran. Pengambilan data dilakukan dengan dengan metode kualitatif deskriptif. Dengan data primer berupa hasil dari kegiatan wawancara dan data sekunder berupa hasil studi kepustakaan. Hasil penelitian menunjukan bahwa tingkat kesejahteraan pelaku seni Ronggeng Amen masih dalam tingkat ekonomi yang kurang. Sehingga hasil analisis memunculkan upaya dalam pengembangan kesenian Ronggeng Amen guna meningkatkan kesejahteraan para pelaku seninya dengan beberapa hal sebagai berikut : Memperbanyak sarana pementasan, Kesadaran Pemerintah Kabupaten Pangandaran, Pembinaan terhadap pelaku seni Ronggeng Amen, Bantuan dan pendanaan terhadap pelaku seni Ronggeng Amen dan melakukan evaluasi langsung oleh pemenrintah daerah kepada pelaku seni Ronggeng Amen
\end{abstract}

\section{Kata Kunci: Kesejahteraan, Kesenian \& Wisata Budaya}

\section{PENDAHULUAN}

Pariwisata merupakan salah satu sektor paling penting dan potensial dalam memberikan kontribusi untuk meningkatkan taraf perekonomian pada suatu negara termasuk negara Indonesia (Satria, Atina, Simbolon, \& Windarto, 2018). Dalam hal tersebut Pariwisata menjadi satu tumpuan dalam pembangunan sebuah wilayah, termasuk pembangunan sebuah kota dalam suatu negara, sehingga sangat wajar apabila pariwisata menjadi sektor andalan dalam pembangunan ekonomi masyarakat dalam meningkatkan kesejahterannya. Di setiap provinsi di Indonesia terdapat kebudayaan yang menjadi daya tarik khusus para wisatawan untuk menikmati setiap kebudayaan. Provinsi Jawa Barat merupakan salah satu provinsi di Indonesia yang juga memiliki banyak sekali tempat wisata yang indah dan tidak kalah manarik dengan provinsi yang lain. Seperti beberapa seni dan kebudayaan yang menjadi ciri khas budaya sunda seperti jaipongan, dan pendak silat. Salah satu daerah di Provinsi Jawa Barat yang memiliki potensi wisata cukup banyak dengan prospek ke depan yang sangat menjanjikan yaitu Kabupaten Pangandaran (Latif, 2019).

Pangandaran merupakan kabupaten yang menjadikannya daerah wisata yang berkembang cukup signifikan sebagai kabupaten yang baru setelah sekarang terpisah dari kabupaten Ciamis. Kabupaten Pangandaran bukan hanya memiliki potensi pariwisata daerah berupa wisata alam, flora, fauna, saja melainkan memiliki wisata budaya yang didalamnya terdapat tari daerah khas tatar sunda yang sudah ada dari sejak dulu dan hingga sekarang menjadi kesenian yang menarik masyarakat di Kabupaten Pangandaran (Permatasari, 2018). Wisata budaya menjadi suatu daya tarik wisata yang sangat menarik, Dengan adanya wisata budaya yang dimiliki suatu daerah dapat disuguhkan kepada 
masyarakat umum melalui suatu pementasan atau pertunjukan guna memperkenalkan pariwisata budaya di Jawa Barat (Syarifuddin, 2017).

Salah satu kesenian yang masih memiliki pasar di masyarakat yaitu kesenian ronggeng amen. Ronggeng merupakan suatu bentuk kesenian yang hidup ditengah masyarakat Sunda. Ronggeng memiiki arti sebutan untuk penari atau pengibing dalam pertunjukan tarian hiburan semacam tayub, ketuk tilu dan sejenisnya (Suherti, 2006). Kesenian Ronggeng Amen memiliki keunikan tersendiri dimana setiap pagelaran atau pementasan selalu menarik banyak masyarakat sehingga banyak melibatkan peran masyarakat di dalamnya. Seni Ronggeng Amen menjadi salah satu kesenian di Kabupaten Pangandaran yang masih memiliki pasar di masyarakat. Jika dilihat dari potensi wisata di Kabupaten Pangandaran yang memang berpotensi besar, Namun dalam pengelolaan wisata budaya masih belum dikelola secara maksimal. Hal tersebut bisa dilihat dari kesenian Ronggeng Amen Pangandaran. Dimana dalam segi pemanfaatan dan intensitasnya belum dimaksimalkan pementasannya secara maksimal. Kondisi yang belum maksimal terhadap keberadaan Ronggeng Amen berpengaruh kepada para pelaku seni yang belum bisa memberdayakan hidupnya dari potensi kesenian Ronggeng Amen. Sehingga dampak dari kondisi tersebut adalah terhadap kesejahteraan, bahwasanya pelaku seni Ronggeng Amen belum tersejahterakan dari kesenian ronggeng amen. Kesejahteraan adalah sebuah kondisi dimana seseorang dapat memenuhi kebutuhan pokok hidupnya salah satunya dengan memiliki pekerjaan yang memadai untuk dapat menunjang kualitas hidup yang lebih baik sehingga kebutuhan hidupnya dapat terpenuhi secara lahir dan batin (Rosni, 2017). Kehidupan ekonomi pelaku seni dalam beberapa rombongan bahwasanya tingkat kesejahteraan pelakunya masih dalam taraf rendah karena belum ada pementasan secara rutin yang diselenggarakan, pelaku seni hanya dibayar per kegiatan saja dan setiap pendapatan tidak ada patokan khususnya. Pada kenyataanya tingkat kesejahteraan pelaku seni Ronggeng Amen masih dibawah tingkat sejahtera. Berdasarkan pemaparan sebelumnya, dimana seharusnya potensi wisata di suatu daerah dapat dikelola secara maksimal guna menciptakan peluang untuk para pelaku seni agar dapat meningkatkan kesejahteraan hidupnya.

Berdasarkan uraian yang telah dikemukakan, maka yang akan diteliti oleh penulis mengenai kesejahteraan pelaku seni dan sejauh mana kesejahteraan pelaku seni sebagai sinergi baru guna mendukung pariwisata Kabupaten Pangandaran.

\section{LANDASAN TEORI \\ Gambaran Kesejahteraan Sosial}

Kesejahteraan Sosial dalam terdiri dari

3 indikator yaitu penduduk, tingkat pendidikan dan kesehatan. Dalam hal ini dimana penduduk tersebut merupakan pelaku seni yang tergabung ke dalam kelompok seni. Jumlah pelaku seni di Kabupaten Pangandaran adalah kurang lebih sebanyak 100 orang yang terbagi ke dalam 18 kelompok seni Ronggeng Amen yang sudah memiliki izin opersional kesenian daerah yang dikeluarkan oleh Dinas Pariwisata dan Kebudayaan Kabupaten Pangandaran. Namun kelompok seni yang aktif berkesenian di kabupaten Pangandaran hanya sebanyak 10 kelompok seni saja, 10 kelompok seni tersebut paling sering pentas dalam acara seperti acara hajatan maupun event dalam pemerintah.

Pelaku seni Ronggeng Amen berkisar rentang usia muali dari 20 tahun sampai ada yang menginjak 60 tahun lebih. Untuk melihat komposisi jumlah pelaku seni Ronggeng Amen Kabupaten Pangandaran bedasarkan umur, sebagai berikut:

\section{Tabel 1. Komposisi Pelaku Seni Berdasarkan Ukuran}




\begin{tabular}{|l|l|c|}
\hline No & \multicolumn{1}{|c|}{ Umur } & Jumlah \\
\hline 1. & $0-12$ & - \\
\hline 2. & $1-4$ & - \\
\hline 3. & $5-7$ & - \\
\hline 4. & $8-12$ & - \\
\hline 5. & $13-15$ & - \\
\hline 6. & $16-18$ & - \\
\hline 7. & $19-25$ & 10 \\
\hline 8. & $36-45$ & 23 \\
\hline 9. & $46-50$ & 43 \\
\hline 10. & $51-65$ & 24 \\
\hline \multicolumn{2}{|c|}{ Jumlah } & $\mathbf{1 0 0}$ \\
\hline
\end{tabular}

Kualitas sumber daya manusia tentunya sangat diperlukan dalam pelestarian maupun pengembangan kesenian Ronggeng Amen sehingga dapat meningkatkan kualitas hidup serta kesejahteraan hidupnya.

Tabel 2. Komposisi Pelaku Seni Berdasarkan Tingkat Pendidikan

\begin{tabular}{|l|l|c|}
\hline No & \multicolumn{1}{|c|}{ Tingkat Pendidikan } & Jumlah \\
\hline 1. & Tidak Tamat Sekolah & - \\
\hline 2. & Tamat SD & 48 \\
\hline 3. & Tamat SMP & 33 \\
\hline 4. & Tamat SMA & 16 \\
\hline 5. & Perguruan Tinggi & 3 \\
\hline \multicolumn{2}{|c|}{ Jumlah } & $\mathbf{1 0 0}$ \\
\hline
\end{tabular}

Berdasarkan tabel 2, mayoritas pelaku seni Ronggeng Amen hanya sampai pada tingkat pendidikan SD, SMP, dan SMA saja. Untuk pelaku seni seperti pemain gamelan pendidikan yang paling tinggi hanya sampai SMP. Walaupun ada beberapa yang sampai jenjang perguruan tinggi.

Salah satu upaya dalam meningkatkan kesejahteraan pelaku seni selanjutnya yaitu dengan melihat kondisi kesehatan. Pelaku seni Ronggeng Amen memiliki kartu program kesehatan yang memang di fasilitasi pemerintah guna meringankan masyarakat seperti BPJS. Mereka menggunakan kartu BPJS pada saat kondisi badan yang tidak fit sehingga yang mereka lakukan adalah pergi ke sarana kesehatan masyarakat seperti puskesmas dengan menggunakan kartu BPJS yang dimana pembiayaan yang ditangguhkan lebih ringan bahkan tidak dipungut biaya.

Seorang pelaku seni dapat memenuhi kebutuhan hidupnya jika kondisi tubuh mereka sehat dan tidak terdapat kendala kesehatan yang terjadi kepadanya.

Gambaran Kesejahteraan Kerja

Kesejahteraan kerja dinilai mampu menunjukan kondisi kesejahteraan dalam aspek pekerjaan sebagai pelaku seni. Kesejahteraan kerja ini dibedakan berdasarkan pementasan manggung yang di lakukan oleh kelompok seni atau sering di sebut lingkung seni. Fasilitas pementasan manggung pada kesenian Ronggeng Amen di Kabupaten Pangandaran dibedakan menjadi 2 yaitu: Pada pementasan Ronggeng Amen di pemukiman dan pementasan kelompok seni pada kegiatan rutin pemerintah.

1. Pada pementasan Ronggeng Amen di pemukiman biasanya dilaksanakan pada acara hajatan pernikahan maupun khitanan. Untuk pementasan di acara seperti hajatan semua peralatan yang dibutuhkan saat manggung di koordinir maupun di sewa oleh pihak kelompok seni saja. Dalam pementasan yang dilakukan di hajatan tidak terdapat peran pemerintah di dalamnya. Sehingga semua kegitan dan acara yang berlangsung hanya berkaitan dengan kelompok seni dan pihak yang membutuhkan jasa saja.

2. Pementasan yang dilakukan merupakan program kegitan rutin yang di selenggarakan pihak pemerintah di pondok seni Kabupaten Pangandaran. Hal tersebut berdasarkan hasil wawancara dengan informan 1 sebagai berikut:

"Di Kabupaten Pangandaran ada salah satu event yang diselenggarakan namanya itu fasilitasi ruang publik, nah biasanya pada akhir pekan itu di tampilkan kesenian Ronggeng Amen di pondok seni Pangandaran, tapi itu bergantian karena di Pangandaran setidaknya ada 4 kesenian yang sudah mendapat legalisasi bahwa itu terindikasi dari Kabupaten Pangandaran yaitu kesenian Ronggeng Amen, Ronggeng Gunung, Lebon dan Badud".

Pelaku seni yang terbagi ke dalam kelompok atau lingkung seni di fasilitasi tempat 
pementasan untuk mementaskan kelompok seninya. Namun baru hanya terdapat 1 tempat pementasan saja. Pementasan yang menjadi program rutin tersebut memiliki sistem pada saat pementasan, dimana sistem yang dilakukan yaitu dengan sistem rolling atau bergantian.

\section{Gambaran Kesejahteraan Keuangan}

Seseorang dapat dikatakan sejahtera dalam hal keuangan jika mereka mempunyai kebebasan keuangan dalam membuat pilihan untuk dapat menikmati hidupnya. Dalam hal ini kesejahteraan keuangan pelaku seni dilihat dari intensits pementasan yang telah dilakukan. Dalam setiap rombongan seni Rongeng Amen memiliki intensitas manggung yang berbedabeda. Rata-rata intensitas manggung yang di dapat dari acara seperti hajatan atau bagi yang membutuhkan jasa. Setiap kelompok mulai dari 5 sampai 10 panggung bahkan terdapat salah satu rombongan pernah mendapat sebanyak 24 sampai penuh 30 panggung dalam waktu 1 bulan. Berikut berdasarkan hasil wawancara dengan informan 2:

"Sebenarnya dari sekarang itu, dari seni memang buruh ringan, yang sampingan namun menjadi pokok atau utama buruh senang, jadi buruh senang itu bagaimana, ibaratnya ada keinginan hanya tinggal berucap, jika sudah jadi untuk rokok dikasih, makan pun semaunya, nah itu dari seni mah.

Namun seiring bertambahnya kelompok seni yang membentuk kelompok kesenian baru membuat intensitas manggung kelompok sebelumnya berkurang. Intensitas manggung yang kurang menyebabkan kurangnya pendapatan yang diperoleh pelaku seni.

Dalam 1 rombongan terdapat 4 warna atau 4 jenis pemain yang membedakan pendapatannya. 4 warna tersebut yaitu nayaga, Ronggeng, soundsystem dan gamelan.

Berikut jenis pemain berdasarkan pendapatan setiap satu kali pementasannya:

\section{Tabel 3. Jenis Pemain dan Pendapatan Pemain Ronggeng Amen}

\begin{tabular}{|c|c|c|}
\hline No & Jenis & Pendapatan \\
\hline 1. & Pemain Kendang & $\begin{array}{l}\text { Rp. } 700.000-\text { Rp. } \\
750.000\end{array}$ \\
\hline 2. & Pemain Goong & $\begin{array}{l}\text { Rp. } 150.000-R p \\
250.000\end{array}$ \\
\hline 3. & Pemain Bonang & $\begin{array}{l}\text { Rp. } 150.000-\text { Rp. } \\
250.000\end{array}$ \\
\hline 4. & Pemain Saron & $\begin{array}{l}\text { Rp. } 150.000-\text { Rp. } \\
250.000\end{array}$ \\
\hline 5. & Pemain Gambang & $\begin{array}{l}\text { Rp. } 150.000-\text { Rp. } \\
250.000\end{array}$ \\
\hline 6. & Pemain Rebab & $\begin{array}{l}\text { Rp. } \quad 300.000 \\
\text { Rp. } 350.000\end{array}$ \\
\hline 7. & Penari Ronggeng & $\begin{array}{l}\text { Rp. } 150.000-R p \\
250.000\end{array}$ \\
\hline 8. & Juru Kawih & $\begin{array}{l}\text { Rp. } 300.000 \quad-\quad \text { Rp. } \\
500.000\end{array}$ \\
\hline
\end{tabular}

Berdasarkan tabel 3 mengenai jenis pemain dan pendapatan yang diperoleh pelaku seni dibedakan menjadi beberapa kelas. Hal tersebut berdasarkan seberapa besar peran pelaku seni dalam pementasan kesenian Ronggeng Amen.

\section{Dampak Pariwisata Terhadap Pelaku Seni Ronggeng Amen}

Salah satunya kegiatan pemerintah yang melibatkan kesenian Ronggeng Amen yaitu:

Berdasarkan permasalahan yang terjadi di Kabupaten Pangandaran, maka peneliti menyampaikan beberapa solusi atau upaya dalam pengembangan kesenian Ronggeng Amen untuk dapat mensejahterakan kehidupan para pelaku seninya, antara lain :

1. Kegiatan Rutin di Pondok Seni Pangandaran

Pemerintah daerah menyelenggarakan kegiatan rutin yang dinamakan fasilitas ruang publik yang dilaksanakan di pondok seni Kabupaten Pangandaran. Kegiatan tersebut dilaksanakan pada setiap akhir pekan yaitu pada sabtu malam dengan mementaskan kesenian khas Pangandaran, yaitu kesenian Kuda Lumping. Sistem pementasan atau kegiatan rutin itu bergantian. Pemerintah daerah memiliki regulasi atau kebijakan terkait jenis kesenian apapun harus mendaftarkan grup atau sanggar seninya sebagai bukti resmi bahwa kesenian tersebut legal dan dapat dipertanggung jawabkan dalam seni kualitasnnya. Kegiatan rutin terlaksana tidak lama setelah Kabupaten Pangandaran lahir. 
2. Pertunjukan dalam Festival atau acara besar Kabupaten Pangandaran

Beberapa event budaya di Kabupaten Pangandaran jelas menghadirkan seni tradisi yang lahir di Kabupaten Pangandaran. Seperti salah satunya acara tahunan yang didalamnya menampilkan kesenian Ronggeng Amen adalah pada upacara hajat laut yang telah menjadi trend Kabupaten Pangandaran. Pemerintah Kabupaten Pangandaran menjadikan kesenian Ronggeng Amen sebagai alat untuk mengumpulkan masyarakat. Sehingga dengan adanya pementasan kesenian Ronggeng Amen banyak masyarakat yang datang pada acara yang diselenggarakan pemerintah tersebut. Namun dilihat dari timbal balik yang diberikan oleh pemerintah daerah kepada pelaku seni Ronggeng Amen belum berdampak sepenuhnya terhadap kesejahteraan pelaku seni.

\section{METODE PENELITIAN}

Penelitian ini dilakukan dengan metode penelitian kualitatif deskriftif. Penelitian kualitatif deskriptif ini cenderung menggunakan analisis induktif. menyatakan bahwa penelitian kualitatif adalah penelitian yang menggunakan latar alamiah, dengan maksud menafsirkan fenomena yang terjadi dan dilakukan dengan jalan melibatkan berbagai metode yang ada (Moleong, 2017). Maka dari itu peneliti menekankan pada suatu analisis yang menggambarkan langsung keadaan dan kondisi realita yang ada.

Pengumpulan data dalam penelitian ini dilakukan secara detail dan mendalam yang melibatkan berbagai sumber informasi seperti wawancara, observasi dan dokumentasi. Data yang diperoleh dalam penelitian ini meliputi data primer berupa data hasil wawancara dan data sekunder berupa studi kepustakaan.

Wawancara dilakukan kepada beberapa orang seperti Pelaku seni Ronggeng Amen, kepala bidang kebudayaan Kabupaten Pangandaran dan ketua paguyuban seni Ronggeng Jawa Barat. Sedangkan observasi dengan cara meunjungi ke kediaman beberapa pelaku seni serta menyaksikan pementasan kesenian ronggeng amen di acara hajatan.

Analis data yang digunakan peneliti dengan menggunakan komponen analisis data interaktif yaitu dengan reduksi data, penyajian data dan penarikan kesimpulan (Sugiyono, 2019).

\section{HASIL DAN PEMBAHASAN} Analisis Kesejahteraan Pelaku Seni Kesejahteraan sosial terdiri dari indikator kependudukan dimana kependudukan tersebut merupakan pelaku seni yang tergabung ke dalam kelompok seni Ronggeng Amen. Sejatinya dalam sebuah kelompok seni tentunya harus memiliki kepengurusan atau anggota yang tetap. Hal tersebut supaya kelompok seni dapat memaksimalkan dan dapat dipertanggung jawabkan dalam aspek kualitas maupun kuantitas suatu kelompok seni tersebut (Mustajab, 2013). Untuk dapat melestarikan kesenian daerah seperti Ronggeng Amen, tentunya harus memiliki regenerasi pelaku seni guna dapat memberdayakan kesenian tersebut agar tidak hilang dimakan waktu (Mustajab, 2013).

Salah satu upaya dalam meningkatkan kesejahteraan pelaku seni yaitu dengan melihat kondisi kesehatan. Kesehatan merupakan pondasi yang berpengaruh terhadap kualitas maupun kinerja para pelaku seni untuk memenuhi tuntutan dan kebutuhan hidupnya (Samranah, 2017). Jika tingkat kesehatan yang rendah akan menurunkan output yang dihasilkan baik dari segi kualitas maupun kuantitas yang akan berdampak pada turunnya pertumbuhan ekonomi pelaku seni. Pendidikan sangat berperan penting dalam usaha untuk mengukur kualitas sumber daya manusia seperti pelaku seni Ronggeng Amen. Pendidikan merupakan salah satu sarana dalam meningkatkan keahlian pelaku seni tersebut. Tujuan pendidikan bukan hanya menjadi seorang individu yang terpelajar, tetapi juga manusia berbudaya serta berkualitas (Sukarma, 2017). Salah satunya dengan menanamkan nilai budaya kepada siswa tentunya harus dilakukan sejak dini. Terdapatnya kegiatan extrakulikuler yang dilakukan di sekolah seperti sekolah dasar, menengah pertama maupun sekolah 
menengah atas berguna dalam pembentukan diri setiap siswa dalam pengetahuan mengenai kesenian daerah.

Kesejahteraan kerja meliputi jaminan kerja kepada pelaku seni serta peran peranan pemerintah terhadap penyediaan sarana penunjang terhadap kesenian Ronggeng Amen. Untuk menciptakan pembangunan dan pengembangan dalam suatu kelompok maupun organisasi tentunya harus memikirkan kondisi kesejahteraan sumber daya manusia yang terdapat di dalamnya. Salah satu faktor penting dalam sebuah kelompok atau organisasi yaitu dengan adanya perlindungan jaminan kerja (Cahyono \& Adhiatma, 2018). Selain itu sarana prasarana dalam menunjang pementasan kesenian sangat penting dalam pengembangan kesenian maupun pemberdayaan pelaku seni di dalamnya (Latif, 2019).

Seseorang dapat dikatakan sejahtera dalam hal keuangan jika meraka mempuanyai kebebasan keuangan dalam membuat pilihan untuk dapat menikmati hidupnya. Kesejahteraan keuangan dibutuhkan persiapan dan perencanaan secara optimal (Yulianti, 2020). Pentingnya manajemen pengelolaam keuangan di dominasi oleh alasan pelaku seni tersebut untuk dapat memenuhi kebutuhan hidup pelaku seni maupun keluarganya. Memperbanyak program rutin yang diselenggarakan pemerintah daerah Kabupaten Pangandaran mengenai kegiatan berbasis kebudayaan daerah merupakan salah satu cara dalam mendapatkan pemasukan pelaku seni. Pendapatan pelaku seni tentunya harus dapat memenuhi kebutuhan hidup pelaku seni.

\section{Analisis Dampak Pariwisata Terhadap Pelaku Seni}

Pembangunan pada sektor pariwisata perlu adanya peningkatan dengan cara memberdayakan dan mengembangkan sumber-sumber dan potensi pariwisata di kawasan wisata tersebut. Meningkatnya sektor pariwisata tentunya berdampak pada aspek-aspek di dalamnya seperti halnya aspek ekonomi (Rulloh, 2017). Dalam aspek ekonomi, dampak pengembangan sektor pariwisata di Kabupaten Pangandaran terhadap pelaku kesenian Ronggeng Amen belum terkoordinir dengan baik. Hal tersebut dikarenakan antara lain intensitas manggung yang diperoleh dalam program penyelenggaran dari pihak pemerintah masih kurang. Peningkatan pariwisata tentunya berdampak pada kesenian daerah. Kesenian dapat dijadikan sebagai daya jual terhadap wisatawan (Prasodjo, 2017). Dinas Pariwisata dan Kebudayaan hendaknya menjalankan tugasnya sebagai fasilitator (Simamora \& Sinaga, 2016). Dengan melihat fasilitas sarana dan prasarana untuk pementasan kesenian daerah dalam rangka sebagai pendukung pariwisata yang belum memadai. Maka hendaknya pihak pemerintah secara serius harus menanggapi perihal kendala yang terjadi di lapangan, karena kelengkapan sarana prasarana pementasan untuk kegiatan kesenian daerah tersebut sangat diperlukan (Simamora \& Sinaga, 2016).

\section{Upaya Untuk Mensejahterakan Pelaku Seni Ronggeng Amen}

1. Peningkatan Kesadaran Pemerintah Kabupaten Pangandaran

Dalam Pengembangan kesenian daerah untuk dapat menjadi daya tarik wisata dengan tujuan menjadi daya jual terhadap wisatawan yaitu perlu adanya dukungan penuh dari pihak pemerintah daerah Kabupaten. Peranan lembaga pemerintah, khususnya di daerah kawasan wisata menjadi faktor penting untuk peningkatan pariwisata tersebut. Sistem pariwisata akan berjalan lebih baik jika digerakkan oleh mekanisme lembaga pemerintah yang telah mencakup semua palaku pariwisata didalamnya (Simamora \& Sinaga, 2016). Pemerintah mempunyai tanggung jawab dalam pelestarian dan pengembangan sebuah kesenian yang terdapat di daerah. Sehingga peran pemerintah dalam pengelolaan untuk menjadi kesenian yang dapat menjadi nilai jual kepda wisatawan sangan dibutuhkan. Hal tersebut dapat membuat intensitas pementasan kesenian dapat berjalan lancar sehingga pendapatan 
untuk para pelaku seninya meningkat.

2. Memperbanyak Sarana Pementasan

Dalam membangun sebuah pariwisata yang maju pemerintah daerah bertanggung jawab memfasilitasi kelompok seni yang aktif berkesenian di daerah tersebut untuk bersama mengembangkan kesenian daerah sesuai dengan kebutuhan yang diperlukan suatu kelompok seni dalam hal sarana prasarana untuk mendukung kegiatan dan program kesenian daerah.

Pementasan kesenian hendaknya harus dikembangkan ke daerah-daerah setempat dengan cara penyediaan fasilitas pentas guna memperkenalkan dan melestarikan kesenian daerah kepada wisatawan. Sarana pementasan tari terdiri dari panggung indoor yang diselenggarakan di panggung terbuka dan outdoor berada di dalam ruangan atau aula maupun pendopo (Endarini, 2017). Dalam hal tersebut bertujuan sebagai penertasi pasar dalam kegiatan penyelenggaraan pementasan kesenian Ronggeng Amen pada tempattempat atau daerah yang memang stategis dengan banyaknya wisatawan yang berkunjung ke daerah tersebut.

3. Pembinaan Terhadap Pelaku Seni Ronggeng Amen

Pengembangan suatu kesenian daerah bukan hanya mengenai fasilitas yang diberikan saja, namunfasilitas non fisik pun sangat dibutuhkan untuk para pelaku seninya. Seperti halnya pembinaan dan perhatian kepada pelaku seni sangat diperlukan. Pembinaan merupakan salah satu upaya pendidikan formal maupun non formal yang dilaksakan secara berencana dan tersususun guna menumbuhkan dan membimbing serta mengembangkan pelaku seni dengan tujuan untuk mengoptimalkan kemampuan sebagai bekal, untuk kedepannya dalam menambah, meningkatkan dan mengembangkan dirinya sebagai manusiawi yang optimal dan pribadi yang mandiri (Sucipta \& Biasa, 2019). Kegiatan tersebut bertujuan untuk memberi ruang, memotivasi serta menumbuhkembangkan kesenian Ronggeng Amen sebagai peluang dalam meningkatkan pendapatan guna mensejahterakan kehidupan pelaku seni.

4. Bantuan dan Pendanaan Terhadap Pelaku Seni Ronggeng Amen

Sebuah kelompok seni atau organisasi untuk dapat berjalan lancar yaitu jika terdapat adanya bantuan maupun pendanaan yang diberikan oleh pemerintah daerah kepada organisasi atau kelompok seni. Bantuan tersebut dapat dijadikan sebagai tunjangan untuk pelaku seni sebagai pengakuan dari pihak pemerintah. Pemerintah hendaknya memikirkan kesejahteraan para pelaku seninya. Dengan menganggarkan dana berupa bantuan langsung tunai kepada pelaku seni Ronggeng Amen. Dalam hal tersebut bantuan berupa dana tunai dapat meringankan pelaku seni jika sedang tidak terdapat kegiatan pementasan manggung.

5. Evaluasi Oleh Pemerintah Kabupaten

Pangandaran Terhadap Pelaku seni

Ronggeng Amen

Dalam sebuah kelompok maupun organisasi perlu dilakukan kegiatan evaluasi terkait pelaksanaan kegiatan maupun pementasan yang telah dilaksanakan sebelumnya untuk mengukur hasil yang telah dicapai dengan tujuan dasarnya. Hal tersebut guna pengembangan kegiatan pariwisata menuju ke arah yang lebih baik (Zulfajri, 2019). Evaluasi dilakukan terkait hal apa saja yang telah dilaksanakan, hal tersebut dilakukan untuk melihat apakah tujuan organisasi kelompok sudah berjalan baik atau tidak dan sesuai harapan atau belum. Pada kesenian Ronggeng Amen hendaknya dilakukan evaluasi terkait intensitas pementasan yang telah dilakukan. Dengan adanya kegiatan evalusi sebuah kelompok seni dapat mengetahui dan mengukur mengenai hal apa saya yang menjadi tolak ukur dalam pementasan sehingga menjadi lebih menarik.

\section{PENUTUP}

\section{Kesimpulan}

Kesejahteraan pelaku seni Ronggeng Amen di Kabupaten Pangandaran dilihat dari usia pelaku seni dikategorikan pada rentang usia produktif sampai lanjut. Dilihat dari 
kesehatan pelaku seni dapat disimpulkan bahwa pelaku seni mayoritas menggunakan fasilitas pemerintah yaitu sarana kesehatan puskesmas dan menggunkan program kesehatan BPJS mandiri. Dilihat berdasarkan tingkat pendidikan pelaku seni maka dapat disimpulkan bahwa mayoritas tingkat pendidikan pelaku seni rendah yaitu hanya sampai SD dan SMP.

Dampak pariwisata terhadap pelaku seni yaitu berdampak terhadap kesenian Ronggeng Amen. Namun untuk kondisi kesejahteraan pelaku seninya belum berdampak secara maksimal.

\section{Saran}

Berdasarkan kesimpulan yang telah disampaikan, hendaknya pihak pemerintah Kabupaten Pangandaran mengembangkan berbagai cara dengan membuat pelatihan seperti sanggar untuk meneruskan jejak pelaku seni sebagai regenarasi dari penerus pelaku seni Ronggeng Amen. Serta pemerintah hendaknya mendukung penug adanya kesenian daerah Ronggeng Amen melalui kegiatan atau event yang berkaitan dengan kebudayaan kemudian menyelenggarakan kegiatan rutin dan dipentaskan di daerah-daerah kabupaten Pangandaran sebagai usaha dalam penetrasi pasar.

\section{DAFTAR PUSTAKA}

[1] Cahyono, B., \& Adhiatma, A. (2018). Peran Modal Sosial Dalam Peningkatan Kesejahteraan Masyarakat Petani Tembakau. 1(1), 131-144.

[2] Endarini, A. (2017). Pelestarian kesenian babalu di sanggar putra budaya desa proyonanggan kabupaten batang.

[3] Latif, S. (2019). Analisis Strategi Pengembangan Wisata Pesisir : Studi Pada Dinas Kebudayaan \& Pariwisata Kabupaten Pangandaran. 7245-7262.

[4] Moleong. (2017). Metode Penelitian Kualitatif. Bandung: PT Remaja Rosdakarya.

[5] Mustajab, A. (2013). Sistem Manajemen Sanggar seni Ambarala Kecamatan Bungoro Kabupaten Pangkep.
[6] Permatasari, D. (2018). Implementasi Peraturan Daerah Kabupaten Pangandaran Nomor 14 Tahun 2015 Tentang Penyelenggaraan Kepariwisataan Oleh Uptd Pariwisata Wilayah Pangandaran. 4, 64-76.

[7] Prasodjo, T. (2017). Pengembangan Pariwisata Budaya dalam Perspektif Pelayanan Publik. 3(1).

[8] Rosni. (2017). Analisis Tingkat Kesejahteraan Masyarakat Nelayan Di Desa Dahari Selebar Kecamatan Talawi Kabupaten Batubara. (2002), 53-66.

[9] Rulloh, N. (2017). Pengaruh Kunjungan Wisata Terhadap Kesejahteraan Masyarakat Sekitar Objek Wisata Berdasarkan Perspektif Ekonomi Islam. 1120.

[10] Samranah. (2017). Faktor-Faktor Yang Mempengaruhi Status Kesehatan Pada Santri Kelas X SMA Di Pondok Pesantren Ummul Mukminin Makasar.

[11] Satria, E., Atina, N., Simbolon, M. E., \& Windarto, A. P. (2018). SPK: ALGORITMA MULTI-ATTRIBUTE UTILITY THEORY ( MAUT ) PADADESTINASI TUJUAN WISATA LOKAL DI KOTA SIDAMANIK. 3(2), 168-172.

[12] Simamora, K. R., \& Sinaga, S. R. (2016). Peran Pemerintah Daerah dalam Pengembangan Pariwisata Alam dan Budaya di Kabupaten Tapanuli Utara. 4(1), 79-96.

[13] Sucipta, K., \& Biasa, M. I. (2019). Peran Parisada Hindu Dharma Indonesia Provinsi DKI Jakarta Pada festival Seni Geguntangan Dalam Melesatarikan Budaya Hindu. (September 2019).

[14] Sugiyono, P. D. (2019). Metode Penelitian Kuantitatif Kualitatif dan R\&D (2nd ed.). Bandung: Alfabeta.

[15] Suherti, O. (2006). Gending ibing lulugu dalam pertunjukan ronggeng tayub di ciamis. (212), 16-26.

[16] Sukarma, I. W. (2017). Pengembangan kearifan lokal seni budaya melalui pendidikan berbasis banjar di bali. 21-32. 
[17] Syarifuddin, D. (2017). SENI PERTUNJUKAN SAUNG ANGKLUNG UDJO KOTA BANDUNG, INDONESIA. 1-9.

[18] Yulianti, D. (2020). Dampak Pengembangan Pariwisata Terhadap Kesejahteraan Masyarakat.

[19]Zulfajri, T. (2019). Pengembangan Festival Sebagai Daya Tarik Pariwisata. 
HALAMAN INI SENGAJA DIKOSONGKAN 